\title{
Zooplankton community structure in the presence of low levels of cyanotoxins: a case study in a high altitude tropical reservoir (Valle de Bravo, Mexico)
}

\author{
Michael A. FIGUEROA-SANCHEZ, ${ }^{1}$ Sarma NANDINI,,$^{2 *}$ S.S.S. SARMA ${ }^{2}$ \\ ${ }^{1}$ Posgrado en Ciencias del Mar y Limnología, Universidad Nacional Autónoma de México, Circuito exterior, Cd. Universitaria, Coyoacán \\ 04510, México City; ${ }^{2}$ Laboratorio de Zoología Acuática, División de Investigación y Posgrado, Edificio UMF, Universidad Nacional \\ Autónoma de México, Campus Iztacala, AP 314, CP 54090, Tlalnepantla, Edo. De México, México \\ *Corresponding author: nandini@unam.mx
}

\begin{abstract}
Valle de Bravo water reservoir in the State of Mexico is being intensively studied since it provides water to about 2,500,000 people living in Mexico City. Cyanobacterial blooms reduce the water quality in this reservoir and this poses health risks. We hypothesize that one of the reasons for these persistent blooms is the dominance of small sized zooplankton throughout the year. Zooplankton samples were collected monthly by filtering $50 \mathrm{~L}$ of water from the surface $(10-20 \mathrm{~cm})$ using a 50 um mesh and the samples were fixed in $4 \%$ formalin in the field. We measured temperature, $\mathrm{pH}$, conductivity, Secchi disk transparency, dissolved oxygen, nitrates and phosphates. The microcystin levels were also quantified. The Secchi depth ranged from 0.86 to $9 \mathrm{~m}$, nitrate levels were low $\left(0.28\right.$ to $\left.2.06 \mathrm{mg} \mathrm{L}^{-1}\right)$, while phosphates were in the range of 1 to $14 \mathrm{mg} \mathrm{L}^{-1}$. The temperature varied from 14 to $25^{\circ} \mathrm{C}$. The zooplankton community was represented by 25 species of rotifers Keratella cochlearis had the highest density $\left(840\right.$ ind $L^{-1}$, followed by Polyarthra vulgaris $\left(750\right.$ ind $\left.L^{-1}\right)$. As compared to previous studies where the genus Brachionus was practically absent, we found four brachionid species. Among cladocerans, Bosmina longirostris was the dominant taxa reaching up to $100 \mathrm{ind} L^{-1}$. Small sized zooplankton $(<200 \mu$ m) dominated throughout the year. The zooplankton biomass in the winter months (December to February) was contributed by Daphnia laevis, copepodites and adult copepods. Unlike a decade ago when adominance by cyanobacteria was recorded, in this study we found that the phytoplankton was dominated by diatoms and chlorophytes with an occasional presence of the cyanobacteria Anabaena spp. and Microcystis spp. The concentration of microcystins ranged from 0.5 to $0.7 \mu \mathrm{g} \mathrm{L} \mathrm{L}^{-1}$ and was within the parameters set by the WHO. Carlson's Trophic State Index and Sladecek's Brachionus/Trichocerca ratio indicated that the reservoir was mesotrophic during the study period.
\end{abstract}

Key words: biomass, cyanobacteria, Mexico, Valle de Bravo, size, zooplankton.

Received: April 2013. Accepted: October 2013.

\section{INTRODUCTION}

There are several lakes and reservoirs in Mexico which cover an area of $2100 \mathrm{~km}^{2}$ and $4810 \mathrm{~km}^{2}$ respectively. The central and eastern part of the country has more than 225 reservoirs (Alcocer et al., 2010). Of these, the reservoir Valle de Bravo (State of Mexico) is particularly important since it provides $38 \%$ of the water to the Cutzamala hydraulic system, which in turn, provides water to Mexico City and the City of Toluca. However, as in many other parts of the world (Jeppesen et al., 2007) this reservoir too suffers from an ongoing process of eutrophication principally due to high inflows of nutrients, mainly nitrogen and phosphorus from anthropogenic sources. As a result, there are frequent, sometimes toxic, cyanobacterial blooms, particularly in the summer months, with the common genera being Microcystis sp., Oscillatoria sp., Anabaena sp., Cylindrospermopsis raciborskii and Nostoc sp. (Berry and Lind, 2010; Gaytan-Herrera et al., 2011). High densities of cyanobacteria reduce the potability of water through enhanced levels of cyanotoxins above the permissible limits of $1 \mu \mathrm{g} \mathrm{L}{ }^{-1}$ of microcystin-LR (Carmichael, 2001; Codd et al., 2005; Alillo-Sánchez et al., 2014). These blooms are also known to have an adverse impact on the aquatic fauna, particularly zooplankton and fish (Kinnear, 2010; Kosten et al., 2012).

The zooplankton community structure is influenced by several biotic and abiotic factors among which food type and density and predation are particularly important (Whitton and Potts, 2000; Cottenie et al., 2001). Several field studies demonstrate that zooplankton densities decrease considerably during cyanobacterial blooms (Burns, 1968; Iglesias et al., 2007). Predation, particularly by vertebrates, is also an important force in structuring zooplankton communities, often in favour of a dominance of small-sized taxa $(<1000 \mu \mathrm{m})$ (Vanni, 1987; Kagami et al., 2002). The corollary is the presence of high densities of small $(<1000 \mu \mathrm{m})$ (rotifers of the genus Polyarthra) and/or evasive zooplankton such as copepods (Ghan et al., 1998). On the other hand, the success of biomanipulation efforts to control cyanobacterial blooms often lies in the ability to control the input of nutrients and to regulate zooplanktivory, especially by fish in order to allow 
high densities of large sized $(>1000 \mu \mathrm{m})$ generalist feeding cladocerans to flourish (Scholten et al., 2005).

The dominant zooplankton groups, in terms of numbers, in most reservoirs including the Valle de Bravo are rotifers, cladocerans and copepods (Contreras et al., 2009) The biovolume and biomass of zooplankton are better indicators of the availability of zooplankton as grazers or as food for fish (Bottrell et al., 1976) but these are rarely reported for many reservoirs. Rotifers and copepods are more selective in their feeding habits than cladocerans (Kirk and Gilbert, 1992). There is a direct relation between the feeding rates and body size of the cladocerans (Brett et al., 1994). In spite of the importance of studies on the zooplankton community size structure, there has been very little work done in this regard in Mexican water bodies. Seasonal variations on the plankton of Valle de Bravo began a decade ago (Ramírez-García et al., 2002) with emphasis on the density and diversity of rotifers, cladocerans and copepods (Nandini et al., 2008; Contreras et al., 2009). Although these studies present a formidable data base of information on the zooplankton of the reservoir they do not discuss their results in terms of zooplankton size. It has been well documented that cyanobacterial densities are often lower in water bodies dominated by large $(>3.0 \mathrm{~mm})$ generalist grazers (Gulati, 1990). We hypothesize that one of the reasons for persistent blooms in Valle de Bravo is the dominance of small sized zooplankton throughout the year. Here we present information on the size structure of the dominant zooplankton taxa in Valle de Bravo and discuss its importance in biomanipulation efforts in the reservoir.

\section{METHODS}

Valle de Bravo $\left(19^{\circ} 11^{\prime} \mathrm{N}\right.$ and $\left.100^{\circ} 09^{\prime} \mathrm{W}\right)$ is a high altitude ( $1780 \mathrm{~m}$ above sea level) drinking water reservoir with a storage capacity of $418.25 \times 10^{6} \mathrm{~m}^{3}$ with an average depth of about $20 \mathrm{~m}$ (Merino-Ibarra et al., 2008; Gaytan-Herrera et al., 2011). Zooplankton samples were collected monthly from June 2010 to May 2011 at three sampling sites (Fig. 1) along with selected physicochemical variables measured at site or at the laboratory (following APHA, 1994) temperature, $\mathrm{pH}$ and conductivity, dissolved oxygen using YSI-55, Secchi disk transparency and chlorophyll $a$. Nutrient concentrations (phosphates and nitrates) were analyzed using a spectrophotometer (YSI 9100). Zooplankton samples were obtained by filtering $50 \mathrm{~L}$ of water from the surface (20$30 \mathrm{~cm}$ ) using a mesh of $50 \mu \mathrm{m}$ and were fixed immediately with $10 \%$ formalin. Quantitative analysis of the zooplankton was carried out using Sedgwick Rafter chamber. For identification of zooplankton we used specialized keys (Koste, 1978; Korovochinsky and Smirnov, 1998). Copepods were classified as nauplii, copepodite and adults. Microcystin levels were quanti- fied using the ELISA immunoassay procedure (Envirologix, Portland, ME, USA).

The size and biomass of the most abundant taxa, three species of rotifers (Keratella cochlearis, Polyarthra vulgaris and Trichocerca similis), three of cladocerans (Bosmina longirostris, Chydorus ef sphaericus and Daphnia laevis) were determined. For copepods we measured nauplii, copepodites and adult of cyclopoids and calanoids. We isolated 50 individuals at random and measured the maximum length and width of each with a Nikon E600 microscope fitted with calibrated camera lucida. The data were then used to calculate the dry weight following Ruttner-Kolisko (1974), Dumont et al. (1975) and Bottrell et al. (1976).

\section{RESULTS}

The physicochemical variables during the study period are shown in the Tab. 1. The temperature ranged between 15 to $25^{\circ} \mathrm{C}$. The $\mathrm{pH}$ was between 7.0 and 10.2 with peak values in September and least values between November to January. The conductivity ranged from 104 to $186 \mu \mathrm{sc}$ $\mathrm{m}^{-1}$ and was nearly similar at all the sites. The water depth was significantly different at the selected sites; it ranged between 1 and $30 \mathrm{~m}$ with a maximum depth of $28.7 \mathrm{~m}$ at site 1 (Tab. 1). The depth at Site 3 ranged from 1.5 and $8.8 \mathrm{~m}$ during the study period. The dissolved oxygen (DO) levels ranged between 3.5 to $10.7 \mathrm{mg} \mathrm{L}^{-1}$ with minimum and maximum in November and February, respectively. The transparency ranged between 1.6 (March to May) to

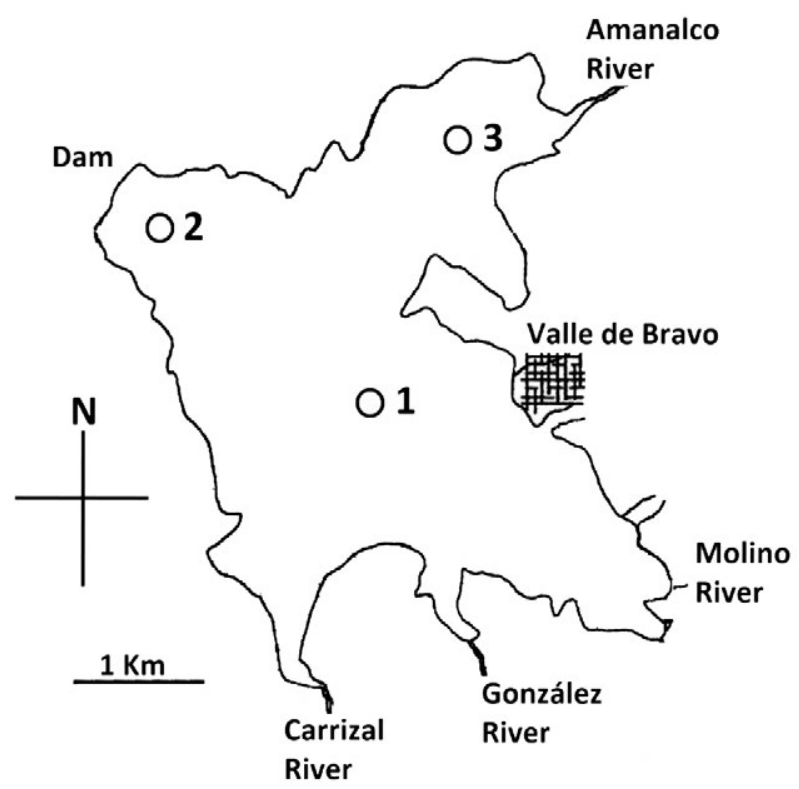

Fig. 1. Map with the sampling points in the Valle de Bravo Reservoir (figure not to scale). 
$9.5 \mathrm{~m}$ (in August) at sites 1 and 2 and between 0.9 to 6.5 $\mathrm{m}$ at site 3 where we also observed high levels of sediments. The nitrate concentrations $\left(\mathrm{N}_{-} \mathrm{NO}_{3}\right)$ ranged between 0.26 (February to March) to $3.52 \mathrm{mg} \mathrm{L}^{-1}$ with peak values in the months of July and December. Phosphate concentrations $\left(\mathrm{P}_{-} \mathrm{PO}_{4}\right)$ were higher and ranged between 1 (January to March) to $14 \mathrm{mg} \mathrm{L}^{-1}$ (in October) with an annual average of $3.38 \mathrm{mg} \mathrm{L}^{-1}$ (Tab. 1). The microcystin concentrations ranged between a minimum of $0.03 \mu \mathrm{g} \mathrm{L}^{-1}$ in December to a maximum of $0.77 \mu \mathrm{g} \mathrm{L}^{-1}$ between February and April (Fig. 2) and were highest at site 1 with peak concentrations of $0.69 \mu \mathrm{g} \mathrm{L}^{-1}$.
The dominant species of phytoplankton from this reservoir were Microcystis, Anabaena, Aphanizomenon, Lyngbya and Coelastrum. Among zooplankton, we recorded 26 species of rotifers, five cladoceran species, cyclopoids and calanoids (Tab. 2). About 35\% of the rotifer species belonged to Brachionidae. The most common rotifers were Keratella cochlearis, Polyarthra vulgaris, Trichocerca similis and Anuraeopsis fissa. K. cochlearis was most abundant (532-840 ind $\mathrm{L}^{-1}$ ) in April but declined to 1-15 ind $\mathrm{L}^{-1}$ JuneJuly and November-December; $P$. vulgaris was also abundant (500-750 ind $\mathrm{L}^{-1}$ ) from March to May (Fig. 3), but became scarce from June to August $\left(20\right.$ ind $\left.\mathrm{L}^{-1}\right)$. Similar

Tab. 1. Seasonal changes, physico-chemical variables in Valle de Bravo Reservoir.

\begin{tabular}{|c|c|c|c|c|c|c|c|c|}
\hline & & $\begin{array}{c}\mathrm{pH} \\
\left({ }^{\circ} \mathrm{C}\right)\end{array}$ & Temperature & Total depth (m) & $\begin{array}{l}\text { Secchi D. } \\
\quad(\mathrm{m})\end{array}$ & $\begin{array}{c}\mathrm{DO} \\
\mathrm{mg} \mathrm{L}^{-1} \text { ) }\end{array}$ & $\begin{array}{c}\mathrm{N}-\mathrm{NO}_{3} \\
\left(\mathrm{mg} \mathrm{L}^{-1}\right)\end{array}$ & $\begin{array}{c}\mathrm{P}^{-\mathrm{PO}_{4}} \\
\left(\mathrm{mg} \mathrm{L}^{-1}\right)\end{array}$ \\
\hline \multirow[t]{3}{*}{ June } & Site 1 & 9.12 & 23.4 & 18.95 & 1.15 & 8.31 & 0.484 & 4 \\
\hline & Site 2 & 9.14 & 23.4 & 17.4 & 1.33 & 8.59 & 0.484 & 4 \\
\hline & Site 3 & 9.13 & 24.9 & 1.95 & 0.85 & 9.16 & 0.484 & 6 \\
\hline \multirow[t]{3}{*}{ July } & Site 1 & 8.84 & 23.4 & 20.3 & 1.39 & 9.58 & 1.76 & 4 \\
\hline & Site 2 & 8.89 & 23 & 13.2 & 1.49 & 9.05 & 3.52 & 2 \\
\hline & Site 3 & 8.88 & 24 & 2.06 & 0.97 & 10.23 & 2.992 & 3 \\
\hline \multirow[t]{3}{*}{ Aug. } & Site 1 & 9 & 21.3 & 24 & 9.5 & 6.57 & 1.76 & 4 \\
\hline & Site 2 & 9.01 & 21.3 & 9.7 & 7.3 & 6.07 & 1.76 & 2 \\
\hline & Site 3 & 9.25 & 22.1 & 8.3 & 6.5 & 6.52 & 2.64 & 4 \\
\hline \multirow[t]{3}{*}{ Sep. } & Site 1 & 9.74 & 20.04 & 30 & 1.2 & 5.57 & 0.836 & 3 \\
\hline & Site 2 & 10.16 & 20.07 & 7.6 & 1.2 & 5.37 & 0.792 & 2 \\
\hline & Site 3 & 9.91 & 21 & 8.8 & 1.1 & 5.72 & 0.836 & 4 \\
\hline \multirow[t]{3}{*}{ Oct. } & Site 1 & 9.34 & 23.7 & 23 & 1.2 & 8.88 & 0.572 & 4 \\
\hline & Site 2 & 9.42 & 20.8 & 15 & 1.3 & 8.46 & 1.1 & 14 \\
\hline & Site 3 & 9.75 & 21.3 & 6 & 1.2 & 8.63 & 2.112 & 8 \\
\hline \multirow[t]{3}{*}{ Nov. } & Site 1 & 7.02 & 19.7 & 27.75 & 4.48 & 3.51 & 1.848 & 3 \\
\hline & Site 2 & 7.08 & 19.7 & 28.72 & 4.87 & 3.48 & 2.64 & 5 \\
\hline & Site 3 & 7.32 & 20.5 & 5.78 & 2.13 & 3.51 & 2.42 & 4 \\
\hline \multirow[t]{3}{*}{ Dec. } & Site 1 & 7.24 & 17.4 & 27 & 6.23 & 4.68 & 1.056 & 3 \\
\hline & Site 2 & 7.21 & 17.5 & 29 & 5.6 & 6.14 & 2.64 & 4 \\
\hline & Site 3 & 7.51 & 14.7 & 6 & 3.78 & 6.29 & 3.52 & 8 \\
\hline \multirow[t]{3}{*}{ Jan. } & Site 1 & 7.38 & 18 & 23.5 & 2.8 & 6.92 & 1.848 & 6 \\
\hline & Site 2 & 7.52 & 17.8 & 21 & 2.65 & 7.38 & 1.628 & 3 \\
\hline & Site 3 & 8.5 & 16 & 5 & 2 & 7.5 & 2.42 & 1 \\
\hline \multirow[t]{3}{*}{ Feb. } & Site 1 & 9.23 & 17.6 & 22 & 2.36 & 10.25 & 0.264 & 1 \\
\hline & Site 2 & 9.55 & 17 & 15 & 1.5 & 10.6 & 0.44 & 1 \\
\hline & Site 3 & 9.37 & 18.2 & 5 & 1.85 & 10.23 & 0.44 & 2 \\
\hline \multirow[t]{3}{*}{ March } & Site 1 & 9.61 & 18.7 & 25.5 & 1.4 & 9.62 & 1.012 & 3 \\
\hline & Site 2 & 9.54 & 18 & 9.3 & 2.5 & 9.23 & 0.88 & 2 \\
\hline & Site 3 & 9.56 & 18.8 & 5.3 & 2 & 9.83 & 0.264 & 1 \\
\hline \multirow[t]{3}{*}{ April } & Site 1 & 9.56 & 21 & 14.7 & 1.19 & 7.94 & 1.936 & 1 \\
\hline & Site 2 & 9.03 & 20.4 & 13.24 & 1.09 & 8.07 & 1.848 & 1 \\
\hline & Site 3 & 8.84 & 19.22 & 1.55 & 2.16 & 7.5 & 2.992 & 2 \\
\hline \multirow[t]{3}{*}{ May } & Site 1 & 9.55 & 24.4 & 19.57 & 1.5 & 9.35 & 0.484 & 1 \\
\hline & Site 2 & 9.48 & 23.8 & 18.18 & 1.2 & 9.21 & 0.792 & 1 \\
\hline & Site 3 & 9.41 & 25.2 & 2.5 & 1.1 & 5.9 & 0.308 & 1 \\
\hline
\end{tabular}

Secchi $D$, Secchi depth; $D O$, dissolved oxygen. 
trends were also observed for $A$. fiss $a$ which reached densities up to 450 ind $\mathrm{L}^{-1}$ during April. T. similis with densities of 90 ind. $\mathrm{L}^{-1}$ was abundant throughout the year. Kellicottia bostoniensis was observed only in the winter months from November to January $\left(3\right.$ ind $\left.\mathrm{L}^{-1}\right)$. During this study period we recorded four species of brachionids for the first time in this reservoir: Brachionus angularis, B. calicyflorus, $B$. caudatus B. havanaensis.

The species richness of crustaceans was generally significantly and lower than that of the rotifers. Bosmina longirostris was present throughout the year with maximal densities of 48-100 ind $\mathrm{L}^{-1}$ in April. Chydorus cf sphaericus reached densities of 20-100 ind $\mathrm{L}^{-1}$ and was dominant in Site 3 during May. The largest cladoceran in the reservoir was Daphnia laevis but was present only from January to March with peak densities of 15 ind $\mathrm{L}^{-1}$ in February. The densities of both, adult cyclopoids and calanoids never exceeded 1 ind $\mathrm{L}^{-1}$; these were observed in greatest numbers at site 3 . Nauplii on the other hand, reached densities of 150 ind $\mathrm{L}^{-1}$. Copepodites, with densities of 70 ind $\mathrm{L}^{-1}$, were abundant in April (Fig. 3). The species diversity (Shannon-Wiener index) varied from 1.63 to 1.92 during the study period. It was highest (2.47) during August but declined to lowest (0.57) two months later (Fig. 4).

Data on the zooplankton body size and biomass are presented in Fig. 5. Most parts of the year, small-sized zooplankton $<200 \mu \mathrm{m}$ dominated. From February to May, densities higher than 800 ind $\mathrm{L}^{-1}$ were contributed by rotifers and nauplii, while larger sized zooplankton (201-600 $\mu \mathrm{m})$ was represented by cladocerans as $B$. longirostris and $C$. $c f$ spaericus. The zooplankton of size $>600 \mu \mathrm{m}$ was observed from November 2010 to May 2011, where of Daphnia laevis was also present for a short period (from January to April). The contribution of large species $(>600 \mu \mathrm{m})$ to the total zooplankton biomass was highest $\left(410 \mu \mathrm{g} \mathrm{L}^{-1}\right)$ in April.

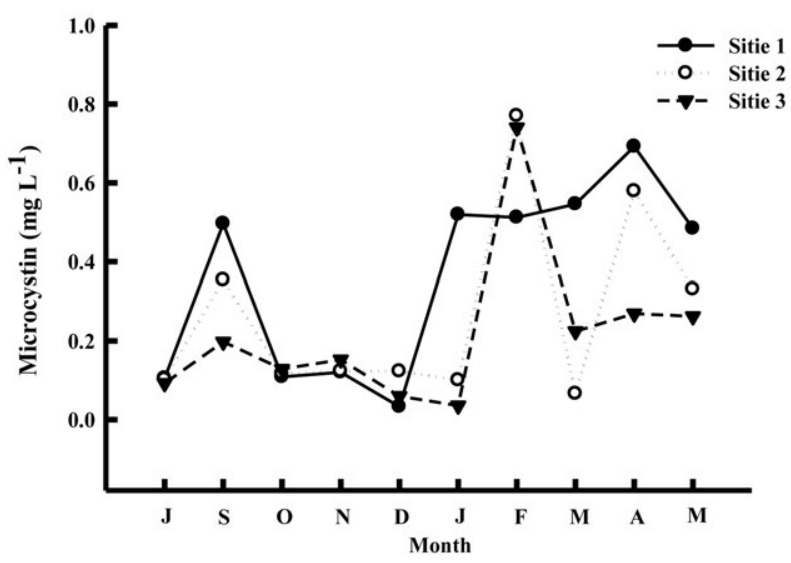

Fig. 2. Seasonal changes of Microcystin from July 2010-May 2011 in Valle de Bravo reservoir.
Tab. 2. List of the species of encountered in Valle de Bravo from June 2010 to May 2011. Species marked with * have been recorded for the first time in the reservoir.

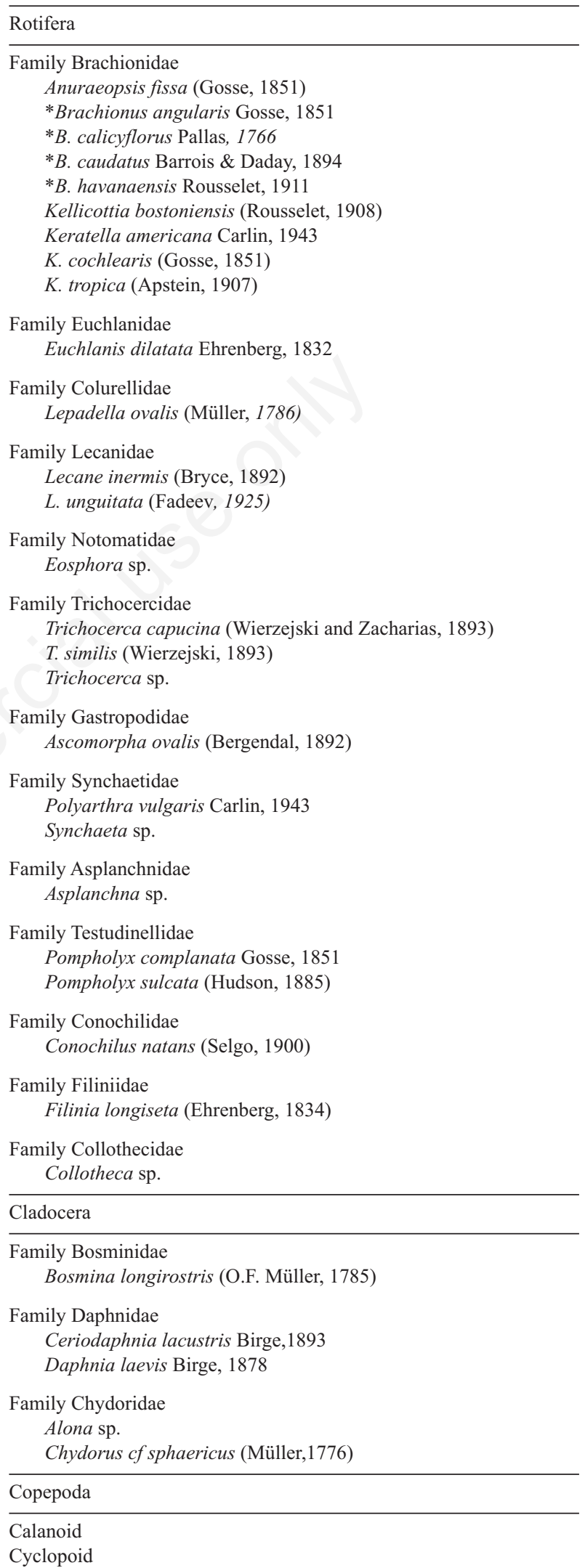



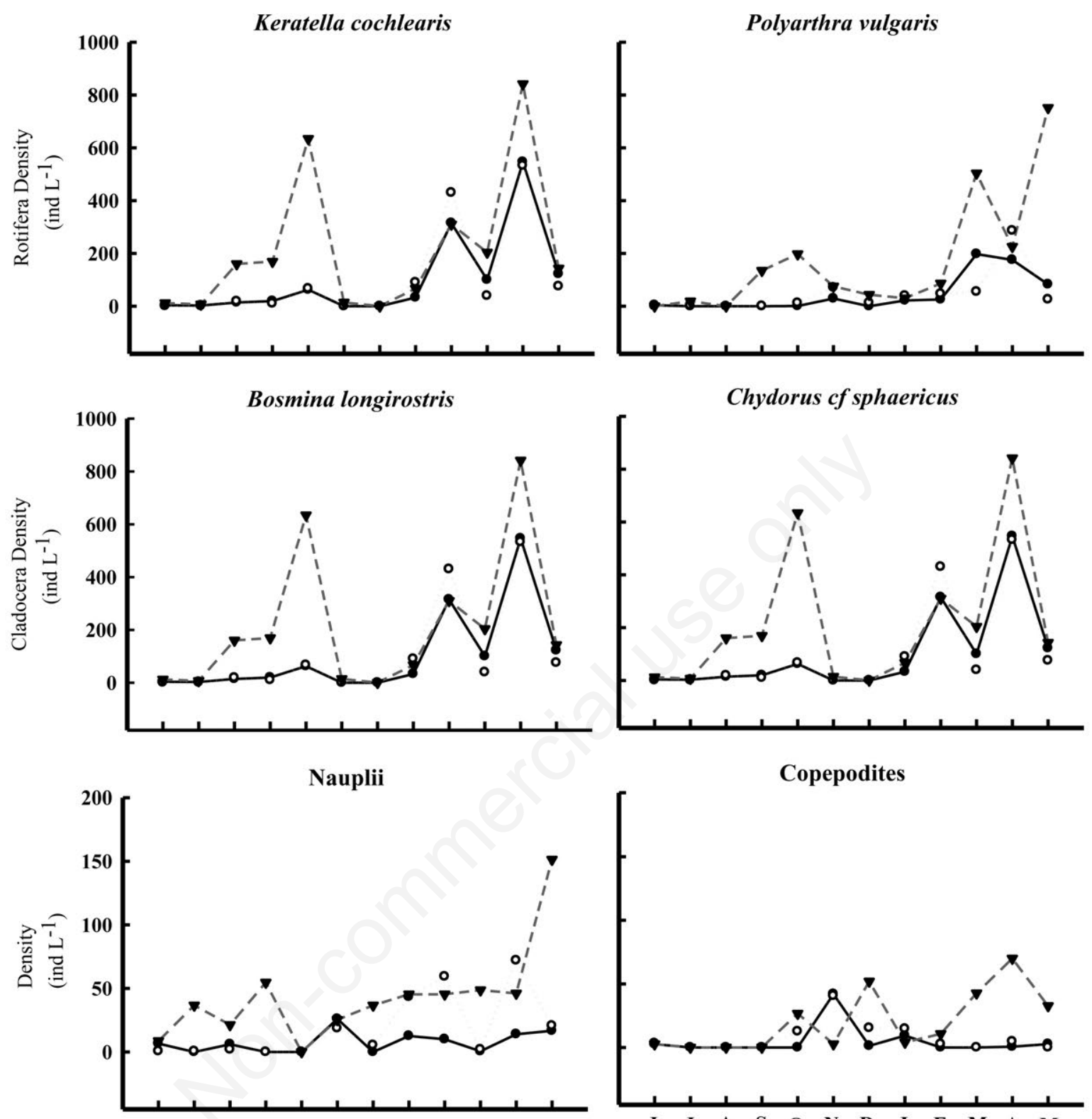

Copepodites
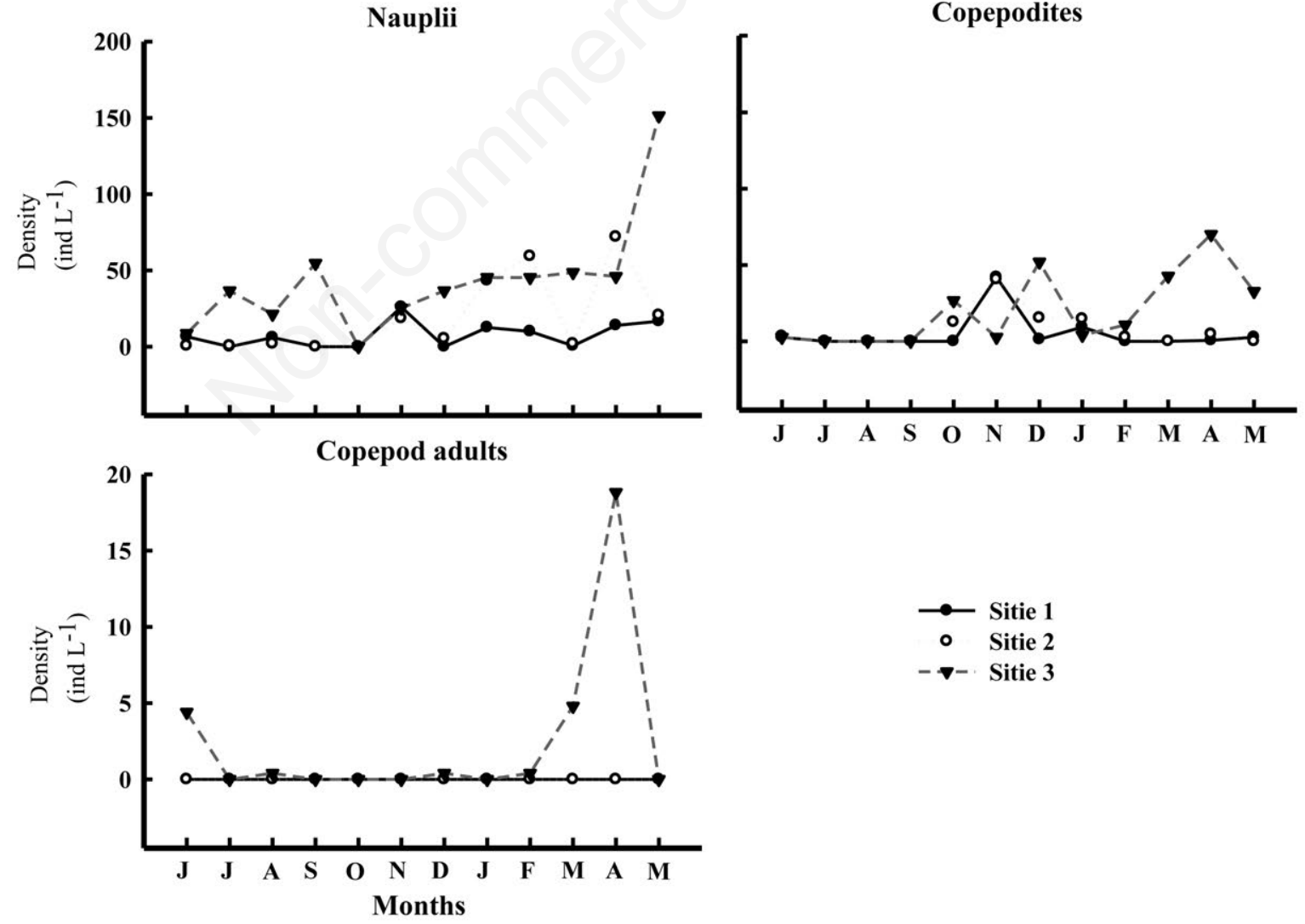

Fig. 3. Seasonal changes in density of the most abundant species of zooplankton in Valle de Bravo from June 2010-May 2011 (check the scale on the Y-axis). 


\section{DISCUSSION}

Although Valle de Bravo is an important source of drinking water to Mexico City, it has also occasionally high densities of potentially toxic cyanobacteria (Vasconcelos et al., 2010). Among them are Microcystis and Anabaena which frequently dominate the phytoplankton community (Ramírez-García et al., 2002; Gaytan-Herrera et al., 2011). Snowella septentrionalis and Aphanizomenon yezoense were also present in this reservoir but these are often non-toxic (Boutte et al., 2008). Although we did not quantify phytoplankton in this study, a recent article published on the phytoplankton of Valle de Bravo Reservoir (Gaytan-Herrera et al., 2011) clearly shows that cyanobacteria are the dominant primary producers in the reservoir. The four most common taxa of cyanobacteria (densities from Gaytan-Herrera et al. 2011), were Microcystis $\left(1 \times 10^{2}\right.$ to $1 \times 10^{5}$ cells $\left.\mathrm{mL}^{-1}\right)$ spp., Anabaena spp. $\left(1 \times 10^{2}\right.$ to $1 \times 10^{4}$ cells $\left.\mathrm{mL}^{-1}\right)$, Aphanizomenon spp. (1 to $1 \times 10^{4}$ cells $\left.\mathrm{mL}^{-1}\right)$ and Lyngbya sp. $\left(1 \times 10^{2}\right.$ to $1 \times 10^{4}$ cells $\left.\mathrm{mL}^{-1}\right)$. The common diatom was Fragilaria sp. $\left(1 \times 10^{2}\right.$ to $1 \times 10^{4}$ cells mL $\left.\mathrm{mL}^{-1}\right)$ while the green-algae was Coelastrum sp. (1 to 999 cells $\left.\mathrm{mL}^{-1}\right)$. The aforementioned taxa have been recorded in concentrations ranging from 1 to $1 \times 10^{6}$ cells $\mathrm{mL}^{-1}$. Cyanobacterial blooms are a common phenomenon in several water bodies in Mexico primarily due to the prevailing high nutrient and temperature regimes found in these habitats (De la Lanza and García, 2002; Berry et al., 2011; Kosten et al., 2012). One of the major health problems associated with cyanobacterial blooms is the presence of toxic microcystins (Carmichel, 1994; Christoffersen, 1996) Although we found that the concentrations of these toxicants were highest in the months of January and February, they were within the stipulated limits of WHO of $<1 \mathrm{mg} \mathrm{L}^{-1}$ (Carmichel, 2001). In our study, in spite of the high levels of nitrates and phosphates recorded at the various sites and the low N:P ratio $(<4: 1)$, common in tropical lakes (Talling and Lemoalle, 1998), we found very low densities of cyanobacteria and a dominance of chlorophytes and diatoms. Canfield et al. (1989) imply that N:P ratios cannot always explain autotrophy succession in tropical water bodies.

As in a few other waterbodies, one of the important factors influencing the formation of cyanobacterial blooms in this reservoir appears to be related to the fluctuation in the water level in the reservoir (Zohary and Ostrovsky, 2011). These fluctuations result in the instability of the system leading to low cyanobacterial bloom formation (Moustaka-Gouni and Vardaka, 2006). In spite of higher concentrations of nitrogen and phosphorus, we found low levels of phytoplankton; so much so that the volume that was routinely filtered based on previous studies (Nandini et al., 2008) was inadequate in order to read the $\mathrm{Chl} a$ concentrations on a visible spectrophotometer. The other important physicochemical variables such as temperature, $\mathrm{pH}$ and dis- solved oxygen were in the same range as has been reported in previous works (Ramírez-García et al., 2002; Contreras et al., 2009). The Secchi depth, in this study, was significantly greater than that reported by Nandini et al. (2008), which corroborates our observations on the low availability of phytoplankton. Our study also reports higher densities of cladocerans than previous works (Nandini et al., 2008); in other water bodies too it has been reported that low densities of phytoplankton associated with high flushing rates are associated with high densities of zooplankton (Moustaka-Gouni and Vardaka, 2006).

Valle de Bravo has been characterized as a eutrophic reservoir (Merino-Ibarra et al., 2008; Nandini et al., 2008; Contreras et al., 2009). However, during this period, we found that the reservoir was mesotrophic based on the Carlson index (Sheela et al., 2011). This improvement in water quality is corroborated by the presence of high densities of chlorophytes and diatoms (Scenedesmus sp. and

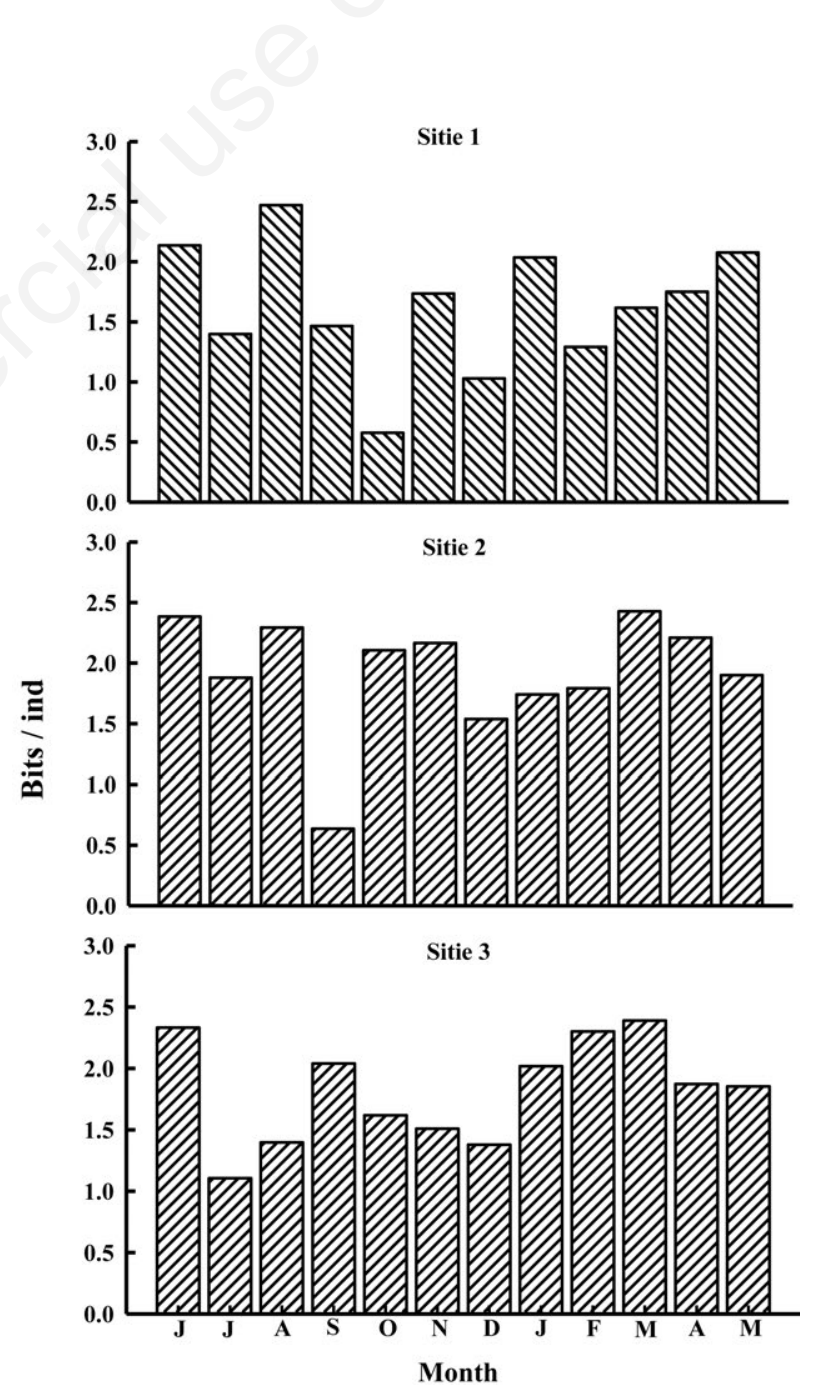

Fig. 4. Seasonal changes in species diversity at different sites in Valle de Bravo reservoir. 
Fragilaria sp.) and the increase in Secchi transparency from a maximum of $<3 \mathrm{~m}$ (Ramírez-García et al., 2002; Contreras et al., 2009) to more than $9 \mathrm{~m}$ recorded in this study. Sladecek (1983) showed that the ratio of the number of Brachionus (B) to Trichocerca (T) indicates the trophic status of water bodies. Unlike the past in which we found few Brachionus, in this study we recorded four brachionid rotifers. Hence we were able to derive a $\mathrm{B} / \mathrm{T}$ ratio of 1.3, characteristic of mesotrophic water bodies (Sladecek, 1983).
This reservoir has rotifer dominance (Ramírez-García et al., 2002) with more microphagous than raptorial (Asplanchna, Synchaeta and Trichocerca) taxa. Peak rotifer densities often reached more than 800 ind $\mathrm{L}^{-1}$ although this was lower than those registered a few years ago (Nandini et al., 2008). Keratella and Polyarthra are commonly dominant in reservoirs (Devetter, 1998); this is also the case in this study. However, unlike previous works (Ramírez-García et al., 2002; Nandini et al., 2008; Contreras et al., 2009), we found four species of the genus
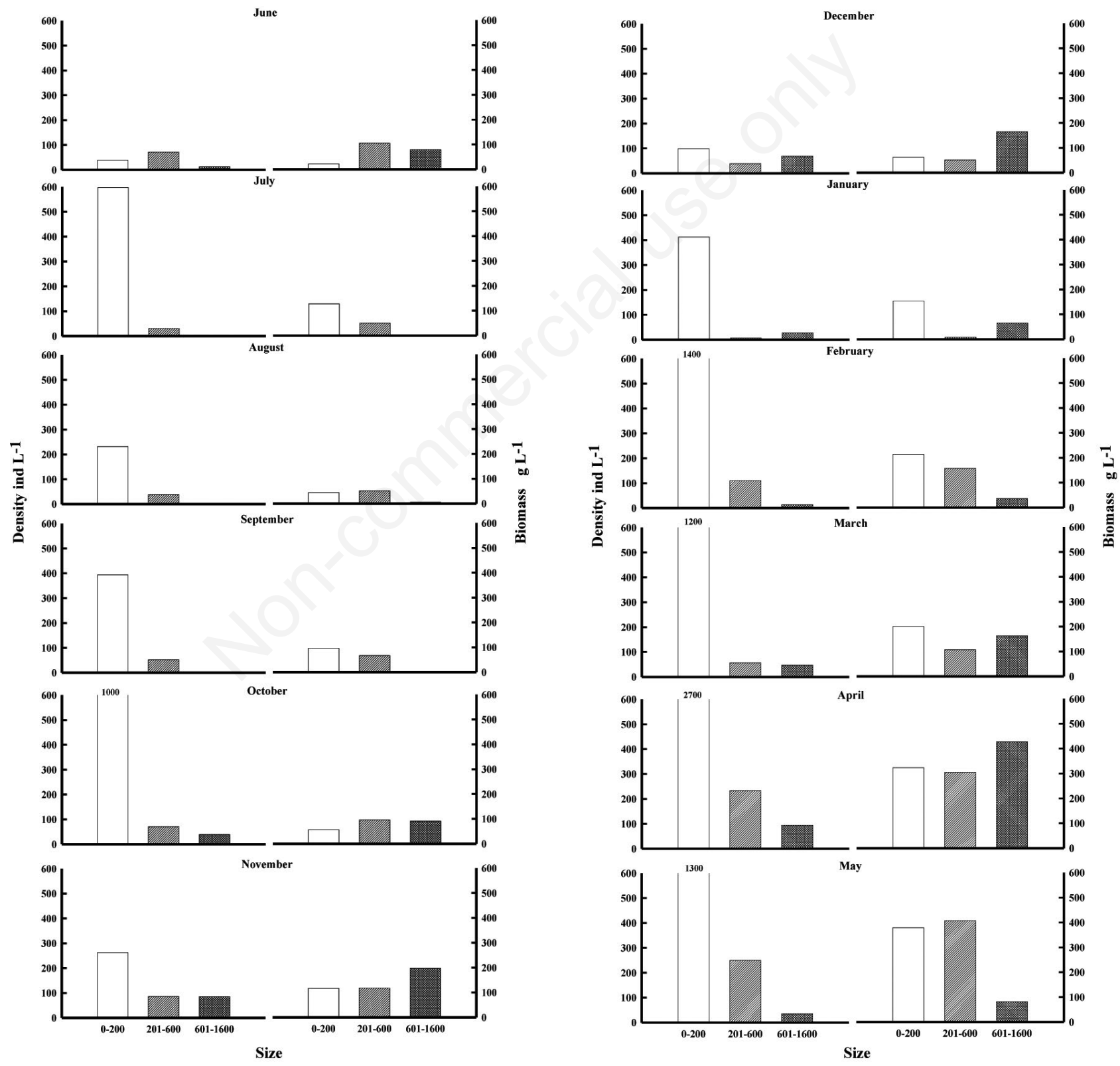

Fig. 5. Relation between density and biomass of zooplankton for different size classes in Valle de Bravo Reservoir from June 2010 to November 2010 (left) and from December 2010 to May 2011 (right). 
Brachionus and a few other rotifer species not reported previously in the Valle de Bravo Reservoir (marked on Tab. 1). This suggests changes have taken place since the first extensive sampling in this reservoir a decade ago, both in terms of the number of species and their densities. Ramírez-García et al. (2002) recorded 245-345 ind L ${ }^{-1}$ of K. cochlearis whereas in this study we found 500-800 ind $\mathrm{L}^{-1}$ of the same species. Among cladocerans the density of Bosmina longirostris also increased significantly, from 100 ind L $^{-1}$ in 2002 (Ramírez-García et al., 2002) to >500 ind $\mathrm{L}^{-1}$ in the present study. The State of Mexico has close to 200 species of rotifers (Sarma and Elias-Gutiérrez, 1997; Sarma et al., 2009) of which around 20\% have been recorded from this reservoir.

Among the cladocerans, there was no significant change in the species richness, with the species Bosmina longirostis, Chydorus sphaericus and Daphnia laevis being the common taxa as in previous reports. However, the density of the cladocerans ranged between 35 to 286 ind $\mathrm{L}^{-1}$ with a maximum in May and though higher than in previous studies, the contribution of this group to the total biomass was very low. As reported in Obertegger and Manca (2011), we also found greater numbers of microphagous rotifer taxa which are known to be associated with low densities of cladocerans. While the species richness was low in Site 1 ( 7 species), the species diversity ranged between 0.57 to 2.47 at all the sites with peak values in spring and summer.

The size structure of zooplankton communities is influenced by food availability (Brett et al., 1994; Torres-Orozco and Zanatta, 1998) and predation (Dodson and Frey, 1991; Iglesias et al., 2011). In water bodies containing cyanobacteria rotifers often dominate (Gliwicz and Lampert, 1990). While there are several studies in Mexico on the species richness and diversity of freshwater zooplankton (Enriquez et al., 2009), the present work examined the size structure of zooplankton communities. This information is important while considering the possible use of zooplankton for lake management (Vanni, 1987). In terms of density, we found a dominance of taxa in the less than $200 \mathrm{~mm}$ range for most of the year 20102011. However, in terms of biomass, dominance due to zooplankton was low almost throughout the year except from February to April when the contribution of large species to the total zooplankton biomass was highest. Gulati (1990) mentions that a minimum of $0.2-0.5 \mathrm{mg} \mathrm{C} \mathrm{L}^{-1}$ of zooplankton is needed to achieve a significant daily clearance of phytoplankton in meso- to eutrophic lakes. In our study, using a factor of 0.48 to convert biomass to carbon (Andersen and Hessen, 1991), the zooplankton biomass ranged from 0.048 to $0.506 \mathrm{mg} \mathrm{C} \mathrm{L}^{-1}$. Except for the months of April and May, the total zooplankton biomass was less than $0.25 \mathrm{mg} \mathrm{C} \mathrm{L}^{-1}$. Thus, in Valle de Bravo, high biomass of zooplankton is found only in the spring; for the greater part of the year zooplankton alone is not enough to control phytoplankton blooms. Chirostoma spp., Lepomis macrochirus and Micropterus salmoides are among the dominant fish species in Valle de Bravo (Renteria et al., 2006). A recent study (GallardoTorres et al., 2013) indicates that these taxa have a significantly higher preference for microcrustaceans than rotifers exerting a high predation pressure on crustacean zooplankton in the reservoir.

\section{CONCLUSIONS}

Comparing our findings to previous studies, we observe that Valle de Bravo has begun to show signs of recovery. The phytoplankton densities were lower compared to the past and the communities were dominated by diatoms and chlorophytes instead of cyanobacteria. However, the high fish predation pressure still appears to control the size structure and biomass of zooplankton in this reservoir; Gallardo-Torres et al. (2013) show that cladocerans, copepods, amphipods and insect larvae are the most preferred prey for three of the previously mentioned fish species in this reservoir. We suggest that the several studies on the diversity of zooplankton in Mexico include data on the size structure and biomass in order to reach generalizations on the potential use of zooplankton in lake management.

\section{ACKNOWLEDGMENTS}

We thank PAPIME PE 208810, PAPIIT (IN213413 and IN213513) and CONACYT (281575) for financial support. Cesar Alejandro Zamora Barrios, Jorge Jiménez Contreras and Diego de Jesús Chaparro-Herrera helped us during field work.

\section{REFERENCES}

Alcocer J, Fernando W, Bernal-Brooks F, 2010. Limnology in Mexico. Hydrobiologia 644:15-68.

Alillo-Sánchez JL, Gaytán-Herrera ML, Martínez-Almeida VM, Ramírez-García P, (2014). Microcystin-LR equivalents and their correlation with Anabaena spp. (Dolichospermum spp.) in the main reservoir of a hydraulic system of Central Mexico. Inland Waters (In press).

APHA (American Public Health Association), 1994. Standard methods for the examination of water and wastewater, Washington: $1220 \mathrm{pp}$.

Andersen T, Hessen DO, 1991. Carbon, nitrogen and phosphorus content of freshwater zooplankton. Limnol. Oceanogr. 36:807-814.

Berry PJ, Lee E, Walton K, Wilson AE, Bernal-Brooks F, 2011. Bioaccumulation of microcystins by fish associated with a persistent cyanobacterial bloom in Lago de Patzcuaro (Michoacan, México). Environ. Toxicol. Chem. 30:1612-1628.

Berry P, Lind O, 2010. First evidence of "paralytic shellfish toxins" and cylindrospermopsin in Mexican freshwater system, Lago Catemaco, and apparent bioaccumulation of the toxins 
in "tegololo" snails (Pomacea patula catemacensis). Toxicon 55:930-938.

Bottrell HH, Duncan A, Gliwicz ZM, Grygierek E, Herzig A, Hillbritcht AI, Kurasawa H, Larsson P, Weglenshka T, 1976. A review of some problems in zooplankton production studies. Norw. J. Zool. 24:319-456.

Boutte C, Mankiewicz-Boczek J, Komarkova J, Grubisic S, Izydorczyk K, Wautelet F, Jurczak T, Zalewski M, Wilmotte A, 2008. Diversity of planktonic cyanobacteria and microcystin occurrence in Polish water bodies investigated using a polyphasic approach. Aquat. Microb. Ecol. 51:223-236.

Brett M, Wiackowski K, Lubnow F, Mueller AS, Elser JJ, Goldman C, 1994. Species-dependent effects of zooplankton on planktonic ecosystem processes in Castle Lake, California. Ecology 75:2243-2254.

Burns CW, 1968. Direct observation of mechanisms regulating feeding behavior of Daphnia in lake water. Hydrobiology 53:83-100.

Carmichel WW, 1994. The toxins of cyanobacteria. Sci. Am. 270:8-86.

Carmichel WW, 2001. Health effects of toxin-producing cyanobacteria: "The CyanoHABS". Hum. Ecol. Risk Assess. 7:1393-1407.

Canfield DE, Jones JR, Ryding SO, Uhlmann D, 1989. Factors and processes affecting the degree of eutrophication, p. 6584. In: S.O. Ryding and W. Rast (eds.), The control of eutrophication of lakes and reservoirs. UNESCO Paris and Parthenon Carnforth.

Codd GA, Morrison LF, Metcalf JS, 2005. Cyanobacterial toxins: risk management for health protection. Toxicol. Appl. Pharm. 203:264-272.

Contreras JJ, Sarma SS, Merino-Ibarra M, Nandini S, 2009. Seasonal changes in the rotifer (Rotifera) diversity from a tropical high altitude reservoir (Valle de Bravo, Mexico). J. Environ. Biol. 30:191-5.

Cottenie K, Nuytten N, Michels E, De Meester L, 2001. Zooplankton community structure and environmental conditions in a set of interconnected ponds. Hydrobiologia 442:339-350.

Christoffersen K, 1996. Ecological implications of cyanobacterial toxins in aquatic food webs. Phycologia 35:42-50.

Dodson SI, Frey DG, 1991. Cladocera and Other Brachiopoda, p. 723-726. In: J.H. Thorp and A.P. Covich (eds.), Ecology and cassification of North American freshwater invertebrates. Academic Press.

De la Lanza EG, García CJL, 2002. [Lagos y presas de México].[Book in Spanish]. AGT, Mexico: 680 pp.

Devetter M, 1998. Influence of environmental factors on the rotifer assemblage in an artificial lake. Hydrobiologia 387:171-178.

Dumont JH, De Velde VI, Dumont S, 1975. The dry weight estimate of biomass in selection of Cladocera, Copepoda and Rotifera from the plankton, periphyton and benthos of continental waters. Oecolologia 19:75-97.

Enriquez GC, Nandini S, Sarma SSS, 2009. Seasonal dynamics of zooplankton in Lake Huetzalin, Xochimilco (Mexico City, Mexico). Limnologica 39:283- 291.

Gallardo-Torres A, Badillo-Alemán M, Merino-Ibarra M, Chiappa-Carrara X, 2013. [Desplazamiento de los charales nativos (género Chirostoma) por dos especies de centrárquidos exóticos invasivos, la lobina negra (Micropterus salmoides) y la mojarra de agallas azules (Lepomis macrochirus): Un estudio de caso en la presa Valle de Bravo, Estado de México].[Report in Spanish]. In: Instituto Nacional de Ecología, University of Prince Edward Island (ed.), [Especies invasoras acuáticas de México: casos de estudio].

Gaytan-Herrera ML, Martinez-Almeida V, Oliva-Martínez M, Duran-Díaz A, Ramírez-García P, 2011. Temporal variation of phytoplankton from the tropical reservoir Valle de Bravo, Mexico. J. Environ. Biol. 32:117-116.

Ghan D, McPhail JD, Hyatt K, 1998. The temporal-spatial pattern of vertical migration by the freshwater copepod Skistodiatomus oregonensis relative to predation risk. J. Fish Aquat. Sci. 55:1350-1363.

Gliwicz ZM, Lampert W, 1990. Food thresholds in Daphnia species in the absence and presence of blue-green algae filaments. Ecology 71:691-702.

Gulati R, 1990. Structural and grazing responses of zooplankton community to biomanipulation of some Dutch water bodies. Hydrobiologia 201:99-118.

Iglesias C, Goyenola G, Mazzeo N, Meerhof M, Rodó E, Jeppesen E, 2007. Horizontal dynamics of zooplankton in subtropical Lake Blanca (Uruguay) hosting multiple zooplankton predators and aquatic plant refuges. Hydrobiologia 584: 79-189.

Iglesias C, Mazzeo N, Meerhoff M, Lacerot G, Clemente J, Scasso F, Kruk C, Goyenola G, Garcia-Alonso J, Amsinck SL, Paggi JC, de Paggi SJ, Jeppesen E, 2011. High predation is of key importance for dominance of small bodied zooplankton in warm shallow lakes: evidence from lakes, fish exclosures and surface sediments. Hydrobiologia 667:133-147.

Jeppesen E, Sondergaard M, Kauridsen TL, Kronvang B, Beklioglu M, Lammens E, Jensen HS, Kohler J, Ventala AM, Tarvainen M, Tátrai I, 2007. Danish and other European experiences in managing shallow lakes. Lake Reserv. Manage. 236:439-451.

Kagami M, Yoshida T, Gurung TB, Urabe J, 2002. Direct and indirect effects of zooplankton on algal composition in situ grazing experiments. Oceanologia 133: 356-363.

Kinnear S, 2010. Cylindrospermopsin: a decade of progress on bioaccumulation research. Marine Drugs 8:542-564.

Kirk KL, Gilbert JJ, 1992. Variation in hervibore response to chemical defenses: zooplankton foraging on toxin cyanobacteria. Ecology 73:2208-2217.

Korovochinsky N, Smirnov N, 1998. [Introduction to the "Cladocera" (Ctenopoda, Anomopoda, Onychopoda and Hapopoda)].[Book in Russian]. Institute of Animal Evolutionary Morphology and Ecology of Russian Academy of Sciences, Moscow, Russia.

Koste W, 1978. [Rotatoria. Die Rädertierte Mitteleuropas].[Book in German]. Gebruder Borntraeger, Berlin: 672 pp.

Kosten S, Huszar VLM, Bécares E, Costa LS, Van Donk E, Hansson LA, Jeppesen E, Kruk C, Lacerot G, Mazzeo N, De Meester L, Moss B, Lürling M, Nõges T, Romo S, Scheffer M, 2012. Warmer climates boost cyanobacterial dominance in shallow lakes. Glob. Change Biol. 18:118-126.

Moustaka-Gouni M, Vardaka E, 2006. Plankton food web structure in a eutrophic polymictic lake with a history of toxic cyanobacterial blooms. Limnol. Oceanogr. 51:715-727.

Merino-Ibarra M, Monrroy-Rios E, Vilaclara G, Castillo FS, Gallegos ME, Ramirez-Ziderol J, 2008. Physical and chem- 
ical limnology of a wind-swept tropical Highland reservoir. Aquat. Ecol. 42:335-345.

Nandini S, Merino-Ibarra M, Sarma SSS, 2008. Seasonal changes in the zooplankton abundances of the reservoir Valle de Bravo (State of México, México). Lake Reserv. Manage. 24:321-330.

Obertegger U, Manca M, 2011. Response of rotifer functional groups to changing trophic state and crustacean community. J. Limnol. 70:231-238.

Ramírez-García P, Nandini S, Sarma SSS, Robles VE, Cuesta I, Hurtado M, 2002. Seasonal variation of zooplankton abundance in the freshwater reservoir Valle de Bravo (Mexico). Hydrobiologia 467:99-108.

Renteria DG, Cota OR, Ortega FE, 2006. [Diagnóstico de la cuenca Valle de Bravo. "Plan para la gestión integral del agua y recursos asociados de la Cuenca de Valle de Bravo, estado de México"]. [Report in Spanish]. IMTA, Report No. GAVMSC-GOA-MEX-05-404-RF-CC.

Ruttner-Kolisko A, 1974. Plankton Rotifers - Biology and taxonomy. Schweizerbart, Stuttgart: 146 pp.

Sarma SSS, Elias-Gutiérrez M, 1997. Taxonomic studies of freshwater rotifers (Rotifera) from Mexico. Hydrobiologia 44:341-357.

Sarma SSS, Serrania-Soto C, Nandini S, 2009. [Rotíferos], p. 113-117. In: Gobierno del Estado de México (ed.), [La Di- versidad biológica del Estado de México]. [Book in Spanish]. México.

Scholten M, Foekman E, Dokkum VH, Kaag N, Jak R, 2005. Eutrophication management and ecotoxicology. Springer, Germany: $150 \mathrm{pp}$.

Sheela MA, Letha J, Sabu J, 2011. Environmental status of a tropical lake system. Environ. Monit. Assess. 180:427-449.

Sladecek V, 1983. Rotifers as indicators of water quality. Hydrobiologia 100:169-201.

Talling J, Lemoalle J, 1998. Ecological dynamics of tropical waters. Cambridge University Press: $441 \mathrm{pp}$.

Torres-Orozco B, Zanatta S, 1998. Species composition, abundance and distribution of zooplankton in a tropical eutrophic lake: Lake Catemaco, Mexico. Biol. Trop. 46:285-296.

Vanni MJ, 1987. Effects of food availability and fish predation on a zooplankton community. Ecol. Monogr. 57:61-88.

Vasconcelos V, Martins A, Vale V, Antunes A, Azevedo J, Welker M, Lopez O, Montejano G, 2010. First report on the occurrence of microcystins in planktonic cyanobacteria from Central Mexico. Toxicon 56:425-431.

Whitton B, Potts M, 2000. The ecology of Cyanobacteria: their diversity in time and space. Academic Press, San Diego: 669 pp.

Zohary T, Ostrovsky I, 2011. Do water level fluctuations matter? Inland Waters 1:47-59. 